\title{
Role of Taizé Music in Catholic Adoration and Protestant Ecumenical Community in Yogyakarta
}

\author{
Hari Martopo \\ Program Studi Musik, Fakultas Seni Pertunjukan \\ Institut Seni Indonesia Yogyakarta \\ Jalan Parangtritis Km 6,5 Kotak Pos 1210 Yogyakarta 55001 \\ Email: harimartopo@gmail.com; HP.: +628175411020
}

Volume 8 Number 1

April 2021: 28-35

\begin{abstract}
Taizés music comes from an ecumenical monastic order with an intense devotion to peace and justice through prayer and meditation. It was founded by Brother Roger Louis Schütz-Marsauche in 1940 in the French village of Taizé and later spread throughout the world. Now the Taizé community is also growing in Indonesia, especially in the city of Yogyakarta. The Taizé community introduced its model of worship consisting of prayer, music, and meditation. The Taizé community entered Indonesia through Ursuline nuns' work, and some of them later chose Taizé music as their worship accompaniment. In Yogyakarta, Taizé music is being used formally in adoration worship, namely The Holy Hour Worship by the Congregational Scholastic Congregation of SCJ Yogyakarta. Simultaneously, an ecumenical community called DNTZ Yogyakarta sings Taizé music in ecumenical fellowship activities. These are voluntary activities which are performed at different places and open for public. These two models of Taizé music in Catholics and Protestants communities have become a unique phenomenon as both communities play an essential role in its development by helping each other and working together in harmony.
\end{abstract}

Keywords: Taizé music; taizé community; worship adoration; ecumenical

\begin{abstract}
ABSTRAK
Peran Musik Taizé dalam Adorasi Katolik dan Komunitas Ekumenis Protestan di Yogyakarta. Musik Taizé berasal dari ordo monastik ekumenis dengan devosi yang intens pada perdamaian dan keadilan melalui doa dan meditasi. Didirikan oleh Bruder Roger Louis Schütz-Marsauche pada tahun 1940 di desa Taizé Prancis dan kemudian menyebar ke seluruh dunia. Kini komunitas Taizé juga berkembang di Indonesia, khususnya di kota Yogyakarta. Komunitas Taizé memperkenalkan model ibadahnya yang terdiri dari doa, musik, dan meditasi. Komunitas Taizé masuk ke Indonesia melalui karya para biarawati Ursulin, dan beberapa dari mereka kemudian memilih musik Taizé sebagai pengiring ibadah mereka. Di Yogyakarta, musik Taizé digunakan secara formal dalam ibadah adorasi, yaitu Ibadah Jam Suci oleh Jemaat Skolastik Kongregasi SCJ Yogyakarta. Bersamaan dengan itu, sebuah komunitas ekumenis bernama DNTZ Yogyakarta menyanyikan musik Taizé dalam kegiatan persekutuan ekumenis. Ini adalah kegiatan sukarela yang dilakukan di tempat yang berbeda dan terbuka untuk umum. Kedua model musik Taizé dalam komunitas Katolik dan Protestan ini telah menjadi fenomena unik karena kedua komunitas memainkan peran penting dalam perkembangannya dengan saling membantu dan bekerja sama secara harmonis.
\end{abstract}

Kata kunci: musik Taizé; komunitas taize; pemujaan pemujaan; ekumenis 


\section{Introduction}

Indonesians are very religious and cultured people. In addition to having a broad national culture, they also retain their local culture. Each citizen must be registered as a religious person or adhere to a particular belief and its identity is written on an official ID card. If a person does not make his or her religious choices, he will be categorized as an atheist who does not believe in God and often experiences social discrimination. There are six official state-recognized religions, including Islam, Catholicism, Christianity, Hinduism, Buddhism, and Kong Hu Chu. Still, the state also recognizes local beliefs that come from ancestors throughout the archipelago. Catholic Christianity is more popularly called Catholic only, as Protestant Christianity is referred to as Christianity only. The Catholic Churches remain one under the management of Konferensi Waligereja Indonesia abbreviated as KWI (the Indonesian Episcopal Conference) while the Protestant Christian Churches are primarily under the coordination of Persekutuan Gereja-gereja di Indonesia abbreviated as PGI (the Fellowship of Churches in Indonesia). Moreover, other types of churches are governed by their own denominations.

There are many ways and models of worshipping practices or worshipping the God Almighty. However, in general, the characteristics are almost the same. In particular, each has its own uniqueness. Indonesia as a democratic country based on the ideology of Pancasila ("Five Principles") has its various cultures and beliefs, but it is not a religious state. Still, it places deity as the central philosophy (the first Principle of Pancasila), and religion is highly respected as a national value through actual practices in public life. Worship that uses music as part of its rituals is not performed on all religions in Indonesia, but the most visible is in the Catholic Church and the Protestant Church. Some religious schools use music, dance, other media, flower arrangements, statues, candles, torches, etc.

Catholics and Protestants in Indonesia perform regular worship, including mass in churches, religious activities officially regulated by state institutions, and other activities determined by their different social communities according to their neighborhood. Every spiritual activity has a meaning and purpose of uniting the diversity among its people. For example, Catholics welcome the month of spiritual pilgrimage every May and October. A spiritual pilgrimage is one of the five forms of devotion or form of prayer that is not an official part of the Catholic Church's general liturgy, but remains a spiritual activity. The Catholic Church understands pilgrimage activities as a journey of repentance, asceticism, and fasting. Pilgrimage is seen as an expression of faith that can display the dimensions of church unity and also as a means of promoting world peace (Martasudjita Pr, 2012). Slightly different, Protestant Christians view pilgrimage as an activity to respect the ancestors. However, it is not a mandatory practice for them as praying can be done at any places as long as it is clean, quiet, not a forbidden place, and can be done solemnly.

Christians generally visit holy cities as pilgrimage destinations, the oldest and significant of which are the sacred cities including Jerusalem in Israel, the Vatican in Rome, Lourdes in France, Santiago de Compostella in Spain, and also the town of Fatima about $142 \mathrm{Km}$ north of Lisbon in Portugal-Fatima church which was last mentioned by Martopo (Martopo, 2015). The pilgrimage's primary purpose is to offer prayers and commemorate the sacrifice of Jesus Christ, wanting to understand the historical relics and traces of the spread of the gospel. Especially Catholics also remember the Virgin Mary as a holy virgin whose name they always say in every prayer. As there is no city that is categorized as "holy" in Indonesia, the Indonesian Catholics tend to visit unique places such as caves, ponds (small lakes as public baths), hills, or old churches that have a particular history-which is generally believed to experience the occurrence or the appearance of the Virgin Mary as a gift of God. They believe that praying in a specific place that has experienced the apparition of the Virgin Mary will bring them a sense of calmness and peace and blessings from God.

Some Indonesians choose a straightforward way of life, adhere to a devout religion, and look like an ascetic. The word "ascetic" can be referred 
to the term "asceticism," which means to live to refrain from worldly temptations and, if necessary, to be miserable. We have a cultural heritage of Hindu and Buddhist traditions, so it can certainly be understood if the askese also develops among religious people. Some Muslims, especially in Java, pray in the ancestral tombs during certain months. It is a combination of traditions to pray and meet relatives on religious holidays; some of the other religions also practice this. It can certainly be understood from the cultural background of Javanese people in Indonesia as Easterners who have a variety of local cultures and are influenced by Hinduism or Javanese faith, when they embrace the "new" religion, they try to be wise by becoming Christians without having to abandon the habits of their ancestors that they consider good. The word "ascetic" is now often used as an additional predicate for an intellectual who works full time even if he has to live a straightforward lifeunrelated to spiritual problems.

In addition to pilgrimages and so on, the Catholic Church cares deeply about using music as an essential part of church worship and celebrations. In Indonesia, the Catholic Church and Protestant Church are very good at developing music for prayer and many other spiritual activities. Actually, the use of sounds and inclusion of musical instruments in prayers also exist in other religions, but one cannot be so careless to use 'music' as a medium of worship which might cause some misunderstanding. This is because the word 'music' is often interpreted as a word from western cultures, considered foreign and is usually avoided by some religious groups other than Christianity. Therefore, there is a need of performing an in-depth research in this topic. Particularly Taizé music which is derived from western culture, is actually a new name and has not been widely understood by the public.

The goal of this paper is to illustrate the essential and unique facts about singing Taizé songs in Yogyakarta with two different models, the first on adoration worship using Taizé music at SCJ Yogyakarta and the second by the ecumenical community of DNTZ Yogyakarta. This paper is published to address one problem: the lack of information about Taizé music development in
Indonesia. Two main sources of information were taken from two research reports of the students involved in this project. Additionally, other sources include relevant authorities, interviews with experts, and literature studies.

\section{Taizé Community}

The Taizé community is an ecumenical Christian monastic brotherhood in Taizé, Saône-etLoire, Burgundy, France. The Taizé Community's brotherhood consists of over a hundred people who consider themselves as brothers from both Catholic and Protestant traditions and come from approximately thirty countries around the world. The Taizé community was founded in 1940 by a brother named Roger Schütz, a Reformed Protestant. It is the Taizé community who was the first to create a type of worship using combinations of prayer, singing and mediation. The background of this community's formation began when Brother Roger was concerned about divisions between Christians during World War II (Praptiningsih, 2018). In the early stages of formation, Brother Roger invited seven other brothers to live the calling of life to devote themselves entirely to the ministry through Taizé prayers.

Information about Taizé began to enter Indonesia by disseminating spiritual missions by the Ursuline Nuns of the Order of Santa Ursula, but it is unknown exactly in which year the Taizé worship started; some sources say that Taizé worship has been known and used since 1990 . Taizé worship can be recognized through groups of monks or nuns, seminaries, youth communities in colleges or schools, groups of young people in churches, and even through other lay groups. Taizé prayer community in Indonesia is known in a Meeting of Bishops in Asia or Federation of Asian Bishops'Confrences (FABC) in Lembang area of Bandung in 1990. At the request of Mgr. Alexander Djajasiswaja, Pr. and Mgr. Leo Soekoto, SJ, the daily event of the meeting was closed every night with the Taizé Meditation Prayer. Therefore Brother Charles (Taizé volunteer from the Korean Taizé community) trained several persons from Betang Batar (Praja Sintang), novitiate Ursuline 
Supratman, and four laymen as executors of the Taizé Prayer. Taizé music and worship applied in Indonesia are not entirely similar to the original version (Adinda, 2016).

In 1999 the Indonesian Taizé Community held a National Taizé Meeting in the Cathedral Parish of St. Peter in Bandung, attended by 400 participants consisting of Catholics (including several priests) and Christians from PGI. The participants came from cities in Indonesia such as Jakarta, Bogor, Cirebon, Purwokerto, Solo, Yogyakarta, Surabaya, Malang, Flores, and Palembang. All joint activities began with Taizé Worship. Today Taizé has become a forum for the development of ecumenical prayer fellowships in various places. There are three historical records of large-scale Taizé activities in Indonesia, namely the Brothers Alois Asia Tour held in Yogyakarta in 2007; Taizé worship and Adoration pre-Indonesian Youth Day (IYD) in Sanggau, West Kalimantan; and Adoration in order to welcome The Seventh Asian Youth Day 2017 in Yogyakarta.

In the early stages of the formation of the Taizé community, music for worship was composed by Brother Roger and later assisted by Jacques Berthier. The Song of Taizé, created by Berthier in 1955, is a repetitive edition of the music and was later canonically recognized in 1975 . Taizés music received attention from the churches and Christians. Taizé worship is praying through meditation and using music as an accompaniment. The increasing animo of Taizé community visitors forced the brothers to translate the lyrics and prayer texts into several languages other than French. They began to translate the lyrics into many languages such as German, Latin, English, and many more. It was intended so that people coming from outside France could better understand the meaning of singing in Taizé worship. According to Scott (Scott, 2013), the Taizé community places music as the primary medium for performing worship. The position of prayer and music become the same; the two form synergy to achieve one goal. Simple music that is repeated continuously will build a meditative atmosphere that helps people get carried away in prayer to feel more of God's presence in their prayers. Subconsciously, people will be carried away into the music melodies and hum the tones of the songs heard.

\section{Taizé Music}

Jacques Berthier initially created Taizés musical character with several songs or songs depicting silence and simplicity so that the listeners could concentrate more while praying. Taizés songs differ greatly from Gregorian songs; although both have strong magnets when it comes to meditation, Taizé music is a representation of a modern form of music that has symmetrical musical phrases and phrases consisting of eight biramas and is played in a repetitive way. Repetition during worship usually occurs eight times, but no definitive information can explain the rules of repetition. The rules can be adapted to the conditions or needs of each Taizé community. The main goal to be achieved through musical arrangements is prayer in meditation.

Berthier originally orchestrated all variations of instrumentation on Taizé music since the Taizé community was founded. Uniquely, if all variants are played simultaneously in the whole formation, the resulting harmony of each instrument becomes a beautiful music. Taizé worship usually uses songs written in a music score. False or unpalatable tones only occur when a player plays a tune or melody that does not match what is written on the song's score. Performing free improvisational techniques while playing songs from Taizé music may damage the harmonies' arrangement that has been formed. The repetitive pattern is naturally an echo of the ancient Christian prayer tradition as in the Rosary prayer in the Western European Church.

Taizés melodic strains become a kind of "mantra" that brings us into worship. Brother Roger fully appointed Jacques Berthier to create musical compositions as an accompaniment to Taizé worship. Berthier, a French organist and composer, initially studied music from his father, a pianist at the Auxxere Cathedral in France. He then continued his music education at Cesar Frank Music School in France and began studying composition from Guy de Lioncourt and learned organ instruments from Edouard Souberbielle. After completing his education, he moved to Paris, 
working as an editor at the Fleurus record company. The same year he was appointed as the organist of the Jesuit Church of Saint Ignace. Berthier's musical work mainly adopts musical idioms created by Joseph Gelineau.

Some rules of mass text or liturgy were once co-created by Gelineau and Berthier. Berthier's great work was the music of Requiem (the musical accompaniment of the death worship or spirit mass), which combined Latin text for the French choir for soloists on a large scale. Berthier also created some rules of liturgical music that the still used by the church till today. Berthier contributed to various monastic liturgy, especially to the Roman Chatolonial communities of En-Calcat, Landevennec, and Maredsous, as well as to the ecumenical community of Taizé.

Taizés musical style is minimalistic, which brings the concept of simple songs and is played repetitively. According to Stein (Stein, 1962), minimalist music consists of melodies, rhythms, and harmonies composed of a specific theme with no duration restrictions. Taizé's music consists of only one section with no theme development on each song. The song "Magnificant," as an example, is a song with a canon structure with a theme song consisting of only eight rhythms. Activities in the Taizé community include praying in silence and singing using music as an accompaniment. The simple sentences in Taizés lyrics are taken from short sentences found in scripture (Larasati, 2013).

Taizés musical structure consists of repetition patterns played by musicians as well as singers. In the middle of the repetition, the verse is usually inserted for solo singers. Lyrics sung by solo singers are generally quoted from psalms. Musical instruments used during Taizé worship play an important role when performing Taizé prayers. In small groups, guitar instruments can help provide the tempo to maintain the rhythm. For a performance in a small prayer room, devotees need at least two guitar players. Guitar instruments can be played with block chord techniques (total tone values) and aperggio techniques. When performing worship, if needed, the sound of the guitar can be amplified using a loudspeaker. If the musician wants to add an electronic organ instrument or keyboard, the volume should be kept low not to disturb the concentration of the people. Guitar instruments may be played louder than the other instruments.

If there are guitar and keyboard players in practice, the sound of the guitar must be louder, and the keyboard sound should be very soft. Additionally, flute instruments and recorders give freshness to Taizé music. There are two types of recorders used in Taizé music: soprano recorder and alto recorder. In large performances, diverse instruments can provide different sonorities and colors in music. The written variations for the melodic instrument are primarily developed from the central theme of the song. The main melody should be played in turns by different instruments according to the musician's agreement. A record that Taizé musicians should always keep in mind, every player must have tolerance so that no one dominates the course of music (Praptiningsih, 2018).

If in practice there are more than two melodic instruments, the musician must play the melody alternately. Several instruments serve as low instruments or instruments that play the underlying chord tones in the lower range, such as cellos, bassons, and trombones. Alternatively, the cello can play bass melodies written on keyboard scores. This rule can be applied as long as the song is played or the cello can also be played in alternating ways with basson and trombone. The goal is to make the sound produced from the harmony of Taizé's songs stronger. Trumpet and french horn are additional instruments in the musical score. Not all song scores list these two instruments. When the musician chooses to use trumpet and french horn, it is recommended to use mute. In small accompaniment performances such as duets and trios, musicians and choirs do not need self-effanial. If the music performance is large and many people are present, it is recommended to use a conductor for better coordination between musicians. Accompaniment music is usually relatively easy to play so that even amateur musicians can play the instrument smoothly. Starting and ending songs are typically arranged in a practice session and mutually agreed upon. Taizé music contains the value of transcendentalism; it is identically 
contained in psalms and hymns, and even other liturgical songs were chosen to accompany Taizé worship. Taizé music is perhaps synonymous with Gothic churches that are not merely stone buildings; but it is also a form of 'transcendentalism in stone' as stated by Worringer (Reed, 2000).

\section{Taizé Music in Adoration of SCJ Yogyakarta}

SCJ Yogyakarta is the Scholastic Congregation of The Priests of the Sacred Heart of Jesus in the form of canonical monasteries or houses of Dehonian Catholic monks and formal educational institutions led by a rector. It was founded on June 23, 1964, in Yogyakarta and became a distinctive and qualified religious community. In this educational city, the brothers and sisters receive an education to develop themselves in six dimensions: (1) Community life; (2) Intellectuality; (3) Humane; (4) Spiritual; (5) Dehonians; and (6) the Apostleship. The activities of all brothers and sisters included not only studying on campus, but also living in a monastery environment (https://cordisscj.blogspot.com). The acronym SCJ is quoted from the Prêtres du SacréCoun de Jésus as a Catholic religious order founded by Leon Dehon in Saint-Quentin, Aisne in France. Thus the priests of the order were popularly called Dehonians.

The congregation originated from the name of the Sacred Heart of Jesus, which was founded on June 28, 1878, which was dissolved in 1884 then re-established using the new name congregation of priests of the Sacred Heart of Jesus. SCJ Yogyakarta, as part of the congregation, then successfully developed Taizé Adoration Worship, an ecclesiastical activity in the form of prayer worship to the Lord Jesus Christ. This worship became a new model in addition to the already well-known Mass of Catholics, worship that puts music at a vital role in addition to prayer and meditation. The process of prayer can be said to use three essential aspects, namely prayer, music, and meditation-just like in Taizé worship in the beginning in France. The adoration manual used in the Scholastic Chapel is the book of Worship Adoration "Menimba Kasih Dari Lambung Jesus Yang Tertikam” written by Pastor John Haryoto, SCJ and Yohanes Sigit Wi- naryo, SCJ (Haryoto \& Winarno, 2013). Because Catholics in Indonesia have different cultural backgrounds than Western cultures, Bahasa Indonesia is used as a language of instruction and also for translations of Latin or English. Taizé songs such as "Adoremus Te Domino"; "Bless the Lord"; and "Bonum est Confidere" does not easily understand, because it is only used by specific communities such as Protestant-Catholic and Christian scholars, monks, priests, or priests. The lyrics of Latin songs are sung as is; for example, is the opening song of worship "Adoremus Te Domino," as follows:

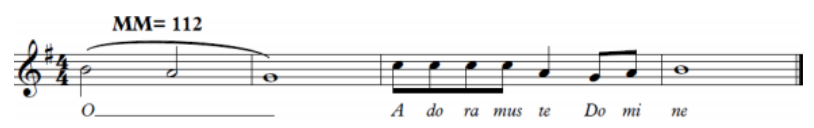

While the English song "Bless the Lord" is translated as below:

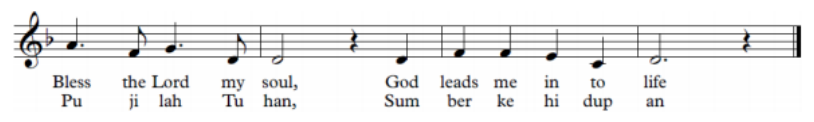

The Latin song "Bonum est Confidere" was also translated. This opening hymn uses recitative and melismatic vocal techniques in a responsorial or intertwined singing style between the priest and the congregation, translated into Bahasa Indonesia, as follows:

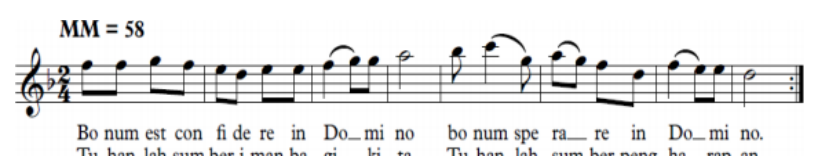

Tu han lah sumber i man ba gi ki ta Tu han lah sum ber peng ha_rap an.

Taizé's musical function is a piece of companion music for prayer and meditation, and it is the same as practiced elsewhere. Thus, Pastor Kristianto, who introduced Taizé music at SCJ Yogyakarta, argued that it is very important for contemplative prayer. Taizé music will help the congregation to concentrate more on praying, and to feel the calm atmosphere that is awakened from the unity of musical harmony. The opinion that Taize music serves to increase spiritual activity is commonly accepted. The church can feel close and receive blessings from the Lord. The Adoration worship built by the priests can be said to use the Taizé Trilogy: Prayer, Music, and Meditation.

The application of Taizé music used for adoration is not entirely the same as Taizés music for Taizé worship/prayer. Adoration is a form of 
devotion of the church, which is a tradition to commemorate the body of Christ. During the worship, the adoration has a lot of quiet time. Quiet time is one of the means to mental readiness to receive God. In contrast to Adoration, Prayer at Taizé Worship incorporates more musical elements in it. Music can build meditative energy that will help people get deeper into their prayers. These two worships have the same purpose, but some parts of worship are slightly different.

Three main parts of the Adoration worship continue to use the accompaniment of Gregorian music: "Prayer before the Blessed Sacrament," "Blessings of the Sacrament," and "Praise to the Blessed Sacrament." Ahead of the Prayer before the Blessed Sacrament, devotees sang the song "Tantum Ergo." The Blessing of the Sacrament uses Gregorian singing. Praise to the Sacrament of the Holy of Holies in the form of a litany sung by pastors and devotees. The main parts of adoration use a melismatic and recitative singing style. There is also the "Prayer of our Father"; some are sung, but some are not. If you choose to sing "Our Father's Prayer," the officer can use the song "Pater Noster" which is not in Taizés music scorebook. Taizé worship did not use Our Father in his prayer arrangements. The elements contained in The Worship of Adoration still use responsorial music.

\section{Taizé Music in DNTZ Ecumenical Fellowship of Yogyakarta}

DNTZ Yogyakarta is a name of prayer and singing fellowship, without organization and complicated rules. DNTZ stands for D (prayer), $\mathrm{N}$ (singing), TZ (Taizé) in Yogyakarta. The alliance has no leaders; all are members who are free to enter or exit their activities. The activities of praying, singing, and meditation are also moving from place to place, and everything is determined by deliberation (Sihotang, 2019). This unofficial model of fellowship is unique and appealing for common people, especially young people. Unlike the adoration worship performed by SCJ Yogyakarta, the company of prayer and singing by DNTZ Yogyakarta is a new phenomenon whose aim is to do ecumenical activities creatively but free from organizational norms as churches and others. This community is in line with opinion that art is a collective creativity that involves the cooperation of various parties with various supporting aspects for creativity (Rokhani, 2019). The musical repertoire for the Taizé fellowship was created as a collective work of art but became a collaborative work in line with the opinion that the artwork does not stand alone on the single breath of religious concepts and dogtrins but has been elaborated with the needs of the local culture as well as the local genius of the occupied society (Sucitra, 2015).

The ecumenical movement developed well but was generally carried out by the churches and its subsidiary institutions. Ecumeny is a universally known and accepted doctrine of faith, thus the word "ecumenical" has always been associated with the subject of religion and understood in the form of Christian churches seeking a union of people based on faith only in Jesus Christ. The word "Oikoumene" is more commonly used than the word "Ecumene," It is used by and protestant Christian churches under the Indonesian Oikoumene Church Synod's organization. Oikoumene Christian Church abbreviated as GKO, among others: GKO Sunter (Jakarta); GKO Kanaan (Bandung City, West Java Province); GKO Purbatua (Padangsidempuan City, North Sumatra Province); GKO Petuo (Sanggau City, West Kalimantan Province); and GKO Agape (Sorong City, Papua Province). From the facts, Protestant churches use the word "Oikoumene" in their names; but there is also the fact that Catholics also use the word "Ecumenical."

Taizé's musical development through two models in Yogyakarta was responded positively by some music teachers who previously did not know enough about it. In small discussions in the classroom or in any other occasions, teachers and students questioned the meaning of the word "ecumenical" or the word "unification" among others: "What is the benefit if only Protestants or Catholics are united?"; "Where are the followers of Christ united?" and "Can the Taizé community and Taizé music unite believers into one universal Christian religion?". Christian, in the discussion it is understood to be one follower of Christ; but it must be divided into many religions that each 
feel most right and end up feeling different from others - even though all Christians realize those differences exist because of history; purely because of the love of Christ. Now there is no more enmity as in the past.

\section{Conclusion}

Taizé music is used in worship by SCJ Yogyakarta which is categorized as a formal activity. On the other hand, it is also used as an ecumenical media by DNTZ Yogyakarta as a voluntary activity. The two models of action are unique and need to get attention and support from the Christian community itself to maintain social harmony and to develop a tolerant attitude among religious people in Indonesia. The basic concept of Taizé worship can be referred to as the Taizé Trilogy consisting of prayer, music, and meditation. This trilogy proved to be beneficial for religious people to unite, to make peace, to draw closer to God and to receive blessings. There is a problem in some Christians, even if they know the word "ecumeny" but do not really know its meaning. Even people who have participated in ecumenical activities also sometimes cannot explain what has been obtained. Discussion topics such as ecumenical; unite all religions that believe in Christ; developing Taizé music by utilizing local folk music as musical enculturation; and so on-are topics or questions expressed as a "dream" only. Whether they matter or not, it is up to the readers to decide.

\section{References}

Adinda, C. P. (2016). Musik Dan Nyanyian Meditatif Pada Ibadah Taizé Di Seminari
Tinggi Santo Paulus Kentungan Yogyakarta. Institut Seni Indonesia Yogyakarta.

Haryoto, S., \& Winarno, Y. S. (2013). Ibadat Adorasi: Menimba Kasih Dari Lambung Yesus Yang Tertikam. PT. Kanisius.

Larasati, J. A. P. (2013). Rumah Komunitas Taize di Bali. Universitas Atma Jaya Yogyakarta.

Martasudjita Pr, E. (2012). Musik Gereja Zaman Sekarang. In Yogyakarta: Pusat Musik Liturgi.

Martopo, H. (2015). Musik Barat Selayang Pandang. Jogjakarta: Panta Rhei Books.

Praptiningsih, A. N. (2018). Musik Taize dalam Ibadat Adorasi Jam Kudus di Kapel Skolastikat Kongregasi SCJ Yogyakarta. Institut Seni Indonesia Yogyakarta.

Reed, H. (2000). Seni Arti dan Problematiknya (Terjemahan Soedarso SP). Yogyakarta: Duta Wacana University Press.

Rokhani, U. (2019). Legitimation of Religious Music of Sabyan Gambus Song "Deen Assalam" as a Perceptive Respon to Islamic Radicalization in Indonesia.. Journal of Urban Society's Arts, 6(2), 128-137.

Scott, C. M. (2013). Taizé Style Music and Contemplatif. Spiritual Growth Ministries.

Sihotang, E. F. (2019). Kajian Musik Liturgi Dalam Ibadah Persekutuan Doa Meditatif Kelompok Doa Nyanyian Taize di Sarasusita Faithful Companions of Jesus (FCJ) Centre Yogyakarta. Institut Seni Indonesia Yogyakarta.

Stein, L. (1962). Structure and style: the study and analysis of musical forms. Summy-Birchard Company.

Sucitra, I. G. A. (2015). Transformasi sinkretisma Indonesia dan karya seni Islam. Journal of Urban Society's Arts, 2(2), 89-103. 